\title{
The Evolution of Relations Between Management and Faculty in Ontario Colleges of Applied Arts and Technology
}

\author{
MICHAEL L. SKOLNIK*
}

Arguably, the greatest barrier to the academic development and functioning of Ontario's twenty-two Colleges of Applied Arts and Technology (CAATs) is the hostile and suspicion laden relationship which exists between management and the union which represents the academic staff of the CAATs - the Ontario Public Service Employees Union (OPSEU). This was the conclusion of the commission on workload in the CAATs which I chaired in 1985 (IARC, 1985) and was corroborated in a study of CAAT governance by a Special Adviser to the Minister of Colleges and Universities the following year (Pitman, 1986). An indication of the degree of concern felt by the Ontario Government regarding managementunion relations in the CAATs is that the largest (in terms of time and resources) public commission on the CAATs to date has been the Colleges Collective Bargaining Commission (Gandz, 1988).

Given the potential for good or harm arising from a labour relations process which impacts indirectly upon more than half a million CAAT students and clients in nearly every Ontario community of at least modest size, it is surprising how little published examination and analysis there has been of labour-management relations in the CAATs. No doubt, the paucity of writing about this facet of the CAATs is part of a larger phenomenon that is the scarcity of books and articles about the development of the CAATs. For example, Volume IV of W.G. Fleming's series, Ontario's Educative Society, published in 1971, just five years after the founding of the CAATs, is still the only book in print on the development of the CAATs; though the history of the CAATs is examined in some books on the development of community colleges in Canada, most notably Dennison and Gallagher's Canada's Community Colleges (1986).

The purpose of this paper is to add to the public record regarding the development of the CAATs in general, and their labour-management relations in particular, by addressing the development of labour-management relations in the CAATs from the early years to the present. My objective is to provide not merely a descriptive treatment of the subject (though that in itself would be useful); but to attempt to present an interpretive analysis, employing the theoretical framework developed by the British Industrial Relations theorist, Alan Fox (1974).

*Professor, Higher Education Group, Ontario Institute for Studies in Education 
The methodology is eclectic. I will draw upon the published sources available, as well as a variety of unpublished documents. In addition, I will make use of notes from the extensive interviews which I and my colleagues on the Instructional Assignment Review Committee (IARC) conducted with government officials, union representatives, faculty, and administrators in the course of our 1985 study and from subsequent visits to the CAATs.

Given the intimate nature of my relationship to the subject matter of this undertaking, some prefatory comments of a personal nature are in order. I first got involved in the study of union-management relations in the CAATs shortly after a bitter three week academic staff strike was ended by controversial legislation. I was subjected to strident personal attacks for having accepted the IARC appointment by the Minister, and subsequent to the publication of the Committee's report I found myself the object of quite personal veneration in some quarters, scorn in other quarters. While the experience of being for a time at the centre of the developments about which $\mathrm{I}$ am writing gave me a degree of accessibility to the subject which is unusual for a university based researcher, it also provided for a potential ego involvement which requires considerable self-reflection and selfdiscipline to keep in check. The problems involved in maintaining objectivity in social science research are well known, and I can add that I have studied these problems (and written on them - Skolnik, 1987) and have done my best to maintain scholarly objectivity in approaching this subject.

The timing and structure of this paper demonstrate two of the strategies which I have employed to enhance objectivity. One has been to wait more than two years since the period of my intense involvement as a third party in CAAT labour-management relations before attempting to address the subject from a scholarly perspective. The other is to analyze the phenomena under study within the parameters of a well established conceptual framework. Indeed, discovering Alan Fox's model was very gratifying, because it seemed to me to illuminate labour-management relations in the CAATs better than any other set of theoretical constructs of which I know, and better than the largely atheoretical approach which, under tight time constraints, the IARC employed in its report.

\section{FOX'S CONCEPTUAL MODEL OF MANAGEMENT-EMPLOYEE RELATIONS}

\section{Trust Relations and Trust Dynamics}

The dominant conclusion of the IARC study was that the academic and working environment in the CAATs was characterized by an extraordinarily low level of trust between faculty and management, and this low level of trust permeated every aspect of college operations which required cooperation, interaction, or simply communication between management and faculty. In reporting our findings, we employed the concept of trust as an ad hoc concept. I was not aware at the time of the extensive literature, for example in group dynamics, in which the concept of trust is developed formally and serves as the basis of theoretical models of human relationships. 
Following Deutsch (1962), Zand (1972: 230) defined trusting behaviour as consisting of actions "that (a) increase one's vulnerability, (b) to another whose behaviour is not under one's control, (c) in a situation in which the penalty (disutility) one suffers if the other abuses that vulnerability is greater than the benefit (utility) one gains if the other does not abuse that vulnerability".

Applying this concept to the employment setting, Fox characterizes a high trust relationship as one in which the parties (i) have a shared view of organizational ends and appropriate means to achieve those ends; (ii) bear a diffuse sense of long term obligations toward one another; (iii) offer one another spontaneous support without narrowly calculating the benefits and costs of each interaction or expecting exact reciprocity in the short run; (iv) give each other the benefit of the doubt in the face of uncertainty of outcomes or incomplete information; and (v) communicate freely and openly with one another. In contrast, in a low trust relationship, parties have divergent views about organizational ends and means; calculate the costs of each concession to the other and demand equivalent benefits in the short term; ensure that the obligations of each to the other are carefully spelled out in prescriptive rules with explicit penalties for non-compliance; are constantly vigilant toward the other's behaviour and quick to invoke sanctions when the rules are even minimally transgressed; and communicate with one another in a carefully guarded and instrumental manner. A major characteristic of a low trust relationship is that each party attempts to restrict the scope for discretionary action of the other.

The nature of the trust relations between parties may change as a result of actions taken by either party, giving rise to trust dynamics. For example, management might introduce new procedures which reduce employee discretion and foster a perception that it no longer bears the same degree of trust toward employees that it once did. Employees might react with more frequent questioning of management judgment or more formal grievances in situations that used to be resolved informally. Faced with such behaviour, management will likely intensify supervision and discipline and communicate more formally with employees, provoking further low trust reactions by employees and accelerating a vicious cycle of low trust move and counter-move. In this example, the initial management actions disrupted an equilibrium and created an imbalance in reciprocity, which, when redressed by the other side, created a negative trust dynamic.

Trust dynamics may be negative or positive, initiated by either party. Generally, because of its greater control over the work setting, management has greater capability to initiate a trust dynamic than do employees or unions. A union can, however, initiate a negative trust dynamic by a sudden flood of grievances, a spontaneous intensification of militancy in bargaining, or a new insistence on formality where previously there had been a tradition of informal interaction with management.

An important consideration for either party in determining whether to initiate a positive trust dynamic is the likelihood that the high trust behaviour will be reciprocated. For management to give workers greater discretion or influence in 
determining work processes and outcomes, it must be reasonably confident that workers will use the increased discretion and influence in ways that it perceives to be in the interests of the organization. A high trust initiative also requires patience, for a party that has felt itself to be abused for a long time may need a sustained high trust initiative by the other side in order to overcome its suspicion regarding the genuineness of the other's intentions. It is not uncommon for employers whose initial overtures are not immediately reciprocated to pull back, saying, "I told you so, we can't really trust the union".

Unions too must be wary, especially when dealing with a management which in the past has shown little tendency to bend rules or give the benefit of the doubt. There is understandable fear that hard won gains may be lost rapidly through the adoption of a more cooperative stance or reciprocation of overtures which, based upon an experience of strained relations, might be perceived as manipulative.

\section{Organizational Compact and Frames of Reference}

Fox suggests two alternative sets of ideological underpinning of relationships between management and employees, which I will refer to as models of organizational compact. These are the spontaneous consensus model (SCM) and the power model (PM).

In the SCM, people are joined together in an organization in a sense of agreement on organizational goals and the means that are perceived as appropriate for achieving them. Consequently, parties accept the division of labour, authority, and discretion vested in different organizational roles as both legitimate and useful for achieving common goals. Usually, if not always, an SCM organization must transcend purely economic goals, for economic ends by themselves provide insufficient symbolic gratification to galvanize social consensus, and as well, economic motivation is inherently divisive. Typically, the SCM requires the articulation of a vision which caters to broad human needs and aspirations and provides a sense of purpose and meaning for those who subscribe to it. An SCM organization, with its agreement about ends and means, is characterized by high trust and a stable equilibrium of reciprocity so long as the vision continues to be meaningful to all parties.

In the power model, complementary needs take the place of agreement on ends and means. The complementary needs are usually of an economic nature: the employer needs workers to produce the product or service that is to be sold for profit; the workers need the remuneration for their services. As well, other needs may be involved, but usually for commodities which are in limited supply, i.e. prestige, recognition, power, etc.

Because it is a marriage of necessity, with the parties having divergent goals, the PM is generally characterized by low trust. Its stability derives from a balance of power, as an accommodation is reached at a point where for each party the anticipated costs of seeking further advantage (or less disadvantage) would outweigh the anticipated benefits of such actions. Such stability is fragile, since 
internal or external environmental changes (e.g. in product or labour markets or in the political climate) which might lead the parties to perceive a change in their relative power could engender attempts to upset the status quo.

The feature which distinguishes these two models is the existence of agreement, or divergence, with respect to organizational goals and means to achieve them. The existence of such agreement is largely a matter of perception. To address this matter of perception, Fox introduces the concept of frames of reference. Frames of reference are perspectives through which people perceive and define social and organizational realities, and these perceptions and definitions shape their behaviour.

Fox distinguishes between unitary and pluralist frames of reference. One who holds a unitary frame of reference perceives the underlying situation to be one of a shared vision of organizational objectives. It is not that all is sweetness and light, but that the underlying reality is perceived as communal and observed differences are treated as superficial or ephemeral, like family quarrels. In the pluralist frame of reference, it is perceived that there is a fundamental divergence of interests among the parties in the organization, no mater how cooperatively or congenially they may work together at certain times or in certain endeavors. As the core reality is defined as consisting of conflicting interests and claims, conflict is deemed to be inevitable, if not desirable. As such, mechanisms and processes for reconciling the inevitable conflicts are deemed to be a vital component of the organizational infrastructure.

\section{Patterns of Management-Employee Relations}

The final element of Fox's conceptual framework is his typology of patterns of management-employee relationships, defined in terms of various combinations of the alternative frames of reference held by the parties. The Traditional pattern is characterized by both management and employees having a unitary frame of reference, perceiving themselves as having common goals, as might be the case of company towns. Management may be benevolent or despotic toward workers, much like masters toward servants.

Classical Conflict obtains where management holds a unitary frame of reference and employees define the situation as pluralist, and hence seek a voice in the affairs of the organization in order to defend or advance their own interests. Should workers organize, management would see unionization as a low trust initiative which threatens to introduce conflict into a situation where there was an underlying harmony. Management denies the legitimacy of the union, and management's use of family and team metaphors is seen by the union as obfuscation, manipulation, and an attempt to undermine the union.

More sophisticated employers may come to feel that there are benefits in having a union - formal mechanisms for order, predictability, discipline, etc. - and that anyway they have no choice but to live with it. Management's acceptance of legitimacy of the union leads to the Sophisticated Modern pattern, in which both 
parties hold a pluralist frame of reference. This pattern is characterized by a high degree of formality (i.e. each party tries to "spin a web of rules around the other") and alternating bouts of intense conflict and wary truce.

The three patterns described above all assume monolithicity on both the management and employee sides, an assumption which is perhaps not realistic in large scale enterprises which have complex structures, varied recruiting patterns, and non-systematic socialization practices, especially in the public sector. Ambivalence and difference of opinion on one or both sides of the relationship defines the Standard Modern pattern. Management may be divided between those (including some who have come through the ranks) who see the union as an appropriate agent of legitimately different interests and those who view it as an inherent source of disharmony in an otherwise communal setting. The struggle among management hawks and doves may present a divided face to the union and introduce oscillations into the relationship, with those who favour a tougher stance frequently gaining the upper hand in times of crisis.

Similarly, the union membership may be divided, with some identifying with "the company" and its goals, others emphasizing the inherently conflictual nature of the relationship ("You have to remember that they're different from us"). Achievement motivated professional workers in particular may prefer to have their individual efforts recognized by management and resent having their communications channeled through the union.

An important source of difference of opinion among union members may be between those espousing different variants of the pluralist frame of reference, particularist and universalist. The former focuses upon matters particular to his or her organization: its functional objectives, work procedures, terms and conditions of employment. The universalist tends to view union activity primarily as a means to change the existing social order, or at least to redress wrongs in society that extend beyond the walls of the organization. In attempting to build a coalition to achieve a given end, the universalist may find it useful to couch his or her demands in the language of particularism.

Sensing the division on the other side, each side may opt for a divide-andconquer strategy, or may develop its own strategy based upon misperceptions of the relative strength of the different factions on the other side, thus making the standard modern pattern a recipe for chaotic and unpredictable labour relations.

A fifth pattern occurs when a sophisticated management perceives benefits from encouraging the formation of a "suitable union" among an older, passive, or inert workforce. In situations where some workers are unionized and some aren't, management may prefer the remaining unassertive group also to unionize so as to facilitate greater consistency in handling labour relations and to legitimize equitable treatment of all groups. Where management, with a pluralist frame of reference, tries to bring along employees who have a unitary frame of reference, the pattern is defined as Sophisticated Paternalist.

The final pattern which Fox identifies, Continuous Challenge, is the other side of classical conflict. Whereas in the latter, the union tries to conduct a relationship 
with a management which denies its legitimacy, in continuous challenge the shoe is on the other foot. Management accepts the legitimacy of the union, from necessity or conviction, but the union challenges every exercise of management prerogative.

These six prototypes are presented as heuristic simplifications of the dominant characteristics of management-employee relations which might stand out at a particular time. As with most typologies of this kind, the phenomena which they describe elude precise measurement. Further, Fox suggests that the patterns of relationships change from time to time, and not necessarily in a predictable manner or developmental sequence. The benefit of this typology, and the related concepts of trust dynamics, organizational compact, and frames of reference, is that it enables one to summarize economically the salient characteristics of the dynamics of relationships between management and employees.

\section{THE DEVELOPMENT OF MANAGEMENT-EMPLOYEE RELATIONS IN THE CAATS: THE EARLY YEARS}

\section{The Social Consensus}

The passage of time has perhaps dulled our collective sense of the sheer magnitude of innovation which the establishment of the CAATs represented. The then Leader of one of the opposition parties in the Ontario Legislature, Donald MacDonald, retrospectively described the creation of the CAAT system as "the most important development in our [Ontario's] over-all education system that has taken place, perhaps, in the past century" (quoted in Hamblin, 1984: 1). Dennison and Gallagher refer to the establishment of new community college systems across Canada in the 1960's as "ushering in a completely new era of postsecondary education" (p. 17) and of the early vision of the colleges as "a major force for new and improved concepts of citizenship in Canada" and an important vehicle for nation-building (p. 275).

Consistent with the social idealism of the 1960's, the establishment of the CAATs embodied one of the necessary conditions for the social consensus model, a vision:

In every new venture there must be a vision of the future, a vision which enables the pioneer to project his thoughts and ideals beyond the arduous first steps. Where goals are clear and high, progress is sure and sound (Ontario, 1965: 1).

The above quotation from the Basic Documents for the CAAT system suggests an almost evangelical spirit, with its reference to ideals and pioneer, and an almost unlimited faith in rationality and progress. The more detailed statements about the goals of the CAATs in that and other documents invoke all of the lofty values about which there was such passion at the time: equality, unlimited development of human potential, progressiveness, and redress of social and economic disadvantage. These were the sorts of organizational goals about which it would have been possible to forge a social consensus. 
Further, the process which led to the establishment of the CAATs was a lengthy and open one in which there was opportunity for the views of all interested parties to be widely presented and debated in numerous advisory and planning committees, newspapers, and television (Watson, 1971: 50). In the event, there appeared to be a strong consensus on the establishment of the CAAT system, except with respect to the single issue of whether the colleges would provide university transfer courses (Fleming, p. 514). Even there, the minority position in favour of transfer was confined mainly to some educators from the universities and to a few opposition members in the Legislature who, Fleming suggests, could find nothing else in the Government's proposals to criticize. While those who have remarked upon the strength of social consensus which undergirded the establishment of the CAATs tended to focus mainly upon the observed sentiments of the most visible parties - members of the Legislature, education associations, and community and business leaders - there is no reason to doubt that these sentiments were not shared also by the newly appointed faculty and administrators of the CAATs, who, after all, were drawn from the very same constituencies. My own observations from having visited the CAATs in the late 1960's and the recollection of all faculty whom I have interviewed on this subject evoke nostalgic reminiscences of the collective euphoria derived from participating in one of the greatest social and educational movements in Ontario's history.

\section{Promoting a Unitary Frame of Reference}

As one might expect in the context of such a strong social consensus, those who designed the CAAT system clearly evidenced a unitary frame of reference. One of the longest sections of the Basic Documents was that headed, "College Committee", which began:

The faculty and student population of a College of Applied Arts and Technology will be more diverse than that of other educational institutions. This fact suggests some problems, but it should be possible to develop a strong sense of unity with the college, thus preventing the rather rigid class system that often prevails in other educational institutions [emphasis added].

The section made substantial reference to various other administration-facultystudent committees besides the College Committee, and the importance of collegial interaction was underscored by the suggestion that provision for the committees be made in the timetable: "a complete shutdown of academic procedures for a two-hour period weekly is suggested".

That the Government was, with at least some of its more visible public statements like those quoted above, exhorting staff to be members of a team, i.e. to adopt a unitary frame of reference, there is little doubt. There is doubt, however, as to whether some of the Government's other actions were consistent with this rhetoric, and as to whether faculty bought into the unitary model. The statements about College Committee, for example, were unaccompanied by any concrete provisions for meaningful faculty participation in academic policymaking. This 
omission was of particular concern to James Renwick, a New Democratic Party member of the Legislature, who claimed that the Minister "had a responsibility to provide, in an imaginative way, within the colleges, a method by which members of the colleges could play a meaningful role in the government of their institutions" (Smyth, 1970: 213). For Renwick, faculty participation, institutional autonomy, an independent Council of Regents, and a commitment to genuine education and not just training, were all interrelated, and he feared that the CAATs would become simply a network of training institutes heavily "dominated by the Minister and his Department". With prescience that borders on grim irony, he warned more than twenty years ago that "the Minister's insistence on excluding the academic community from participation in the governance of the colleges was going to be a matter which would result in difficulties until such exclusion had been rectified" (p. 214). Supporting Renwick's position, Stephen Lewis argued that the exclusion of faculty from decision making was "antagonistic to the kind of intellectual creativity ... which should be characteristic of the new institutions", and Donald MacDonald alleged that the Government had "set up a 19th Century structure for the colleges" (pp. 215-216).

As the documentation on the establishment and early years of the CAATs concentrates upon the statements of the key opinion leaders in the Province, it is not known how widely, if at all, the concerns noted above were shared by faculty in the CAATs. Indeed, while Renwick and company were challenging the Minister in the Legislature, the CAAT faculty were sinking into an imbroglio of confusion over representation, and it is not clear just who the effective spokespersons for the faculty were. Such statements from CAAT faculty as were reported in provincial newspapers concentrated upon bargaining rights and salaries. This together with the fact that faculty participation in college decision making did not become a major public issue until the 1980 's suggests that there was not widespread discontent among faculty with the vision of the CAATs enunciated by the Minister. Or it may have been that faculty were too enamoured of their new roles and too excitedly busy with discharging their new responsibilities to critically evaluate the larger designs which emanated from Queen's Park. Probably a definitive judgment on the matter is impossible, but it is likely that novelty and abundant money papered over the latent cracks of divisiveness, resulting, for a time, in a fragile unitary frame of reference among the majority of faculty.

\section{The Development of Collective Bargaining Relationships}

The development of collective bargaining in the CAATs has yet to come under the historian's glass, but some documentation is provided by Fleming (pp. 551-555) and Smyth (pp. 384-391), as well as newspaper archives. As many staff of the former Trades and Technology Institutes which were incorporated into the new colleges had been members of the Civil Service Association of Ontario (CSAO, which later evolved into OPSEU) or of federations with bargaining rights, it was assumed that CAAT staff would become organized in some fashion. Fleming 
reports that Boards of Governors of some colleges were seeking the authority to do their own bargaining, but that the Government's desire for Provincial control over the colleges precluded any chance that this right would be conceded to the boards (p. 528). As developments unfolded, faculty were eventually given two options from which to choose, but never did they have the choice of voting for local bargaining.

Following a decision of the Ontario Labour Relations Board which threw out a certification application from the faculty of Fanshawe College on the grounds that Fanshawe was a Crown Agency and hence the OLRB had no jurisdiction, the CSAO approached the Council of Regents and claimed that it was entitled to exclusive bargaining rights for CAAT staff under The Public Service Act. The Negotiating Committee of the Council of Regents responded by recognizing the CSAO as bargaining agent, without consultation with colleges or their faculty (Little, 1969: 23). It is not entirely clear whether the negotiating committee took this action because (a) it thought that it was required to so under The Public Service Act; (b) it seemed the most expeditious course of action; or (c) this was the bargaining arrangement preferred by the Government. Interviews with faculty reported by the press suggest a perception that (c) was the correct answer, as the Government was used to dealing with CSAO and was comfortable with its concentration upon pecuniary, as opposed to educational, issues (The Globe and Mail, February 2, 1970; Zwelling, 1971). Insofar as this perception was accurate, the earliest pattern of management-employee relations in the CAAT system had elements of Sophisticated Paternalist. However, even in this early period the management side was hardly unified, as a majority of CAAT Boards of Governors passed a resolution in December, 1968, calling upon the Council of Regents to cease bargaining on behalf of the Boards.

Be that as it may, the next significant event was in January, 1969, when a group of faculty, on behalf of the Ontario Federation of Community College Faculty Associations, obtained a court injunction preventing the CSAO from exercising bargaining rights for the faculty. Subsequently, Judge Walter Little, who had been appointed Special Adviser to the Ontario Government concerning collective bargaining in the Public Service and Crown Agencies and Commissions, noted that the CSAO did not have a "significant" number of members of the academic staff to constitute a basis for representation and its right to represent faculty had been challenged by another group. In this situtation, Judge Little declined to make any recommendation as to what agent should represent the academic staff. Shortly thereafter, the Government announced its intention to introduce legislation which would establish procedures for employees of the CAATs "within appropriate bargaining units" to select their bargaining agent (Davis, 1970). Many CAAT faculty remained skeptical of the Government's intentions, fearing that the Government would somehow manipulate them into the CSAO. The Federation of College Faculty Associations pressured for consultation on the legislation and organized a one day walk-out to emphasize its concerns. A vote was finally held in January, 1971, and by a narrow margin the CSAO was selected over the Federation to be the bargaining agent in Province-wide negotiations. It is 
noteworthy, however, that in large part, the events which led to the determination of the faculty bargaining unit were heavily dominated by political machinations external to the colleges, and that the normal processes for forming bargaining units were never experienced directly by most faculty and college managers. Insofar as the experience of management and employees going together through the various stages that are typical in the establishment of a bargaining relationship facilitates the development of a healthy relationship, it might be observed that this relationship started off on the wrong footing by omitting those stages.

In recognition of the strong divisions of opinion on the faculty side, the Government had, through allowing, if not encouraging, a representation vote, moved the bargaining pattern from the Sophisticated Paternalist a good ways toward the Standard Modern. Still, as long as the CSAO was something short of a full-fledged union and the faculty were denied the right to strike, taints of paternalism lingered on. The last vestiges of the paternalistic phase ended in 1974 when CAAT faculty became the first members of CSAO to defy the compulsory arbitration provisions of the Crown Employees Collective Bargaining Act and boycott the arbitration hearings which the legislation provided as the final dispute resolution mechanism, prompting the Chairman of the Council of Regents to charge that the CSAO was using the CAAT faculty bargaining unit to gain the right to strike for the public service (The Toronto Star, September 16, 1974).

Whatever the validity of this charge, it reflected a concern held by many - and for different reasons - about the appropriateness of incorporating education professionals within a large public service union most of whose members were less educated, less well paid, and had different employment interests than the CAAT faculty. In particular, a great many of the early faculty of the CAATs were recruited from the lower and middle ranks of industry, as well as owners and managers of small companies, and many of these were uncomfortable with the idea of participating in a union. On a more general plane, Dennison and Gallagher argue that the public service model of college unionism "falls short in not recognizing the distinctiveness of the college as a workplace" and in "not acknowledging the professional character of college instruction and the professional training of those who provide it" (p. 225). A more pointed concern is that the interests of the colleges, as they are represented through the formal labour relations process, might take a back seat to the larger interests of the public service union.

Such concerns have led disaffected faculty on more than one occasion, since the 1969 court injunction, to attempt to have the CAAT faculty unit removed from OPSEU. For example, in 1977, teachers from at least seven colleges tried to promote a withdrawal of the faculty from OPSEU, charging that their membership in the public service union frustrated attempts of teachers to address educational issues and gain participation in college decision making comparable to that which university professors had. The President of OPSEU downplayed such concerns, noting that as the union represented "many interests, with at least 1,600 classifications, it would be easy to take many groups and single them out as being unique" (The London Free Press, April 18, 1977; see also The Ottawa Citizen, same date). The differences of opinion among faculty with respect to the 
appropriateness of the public sector model to their educational and professional interests is but one of many indications of the heterogeneity of their perceptions of workplace issues (others of which will be indicated in the next section), illustrating the ambivalence and division on the faculty side characteristic of the Standard Modern pattern of management-employee relationships.

By the mid-Seventies, such ambivalence and division had become apparent also on the management side, where a perennial problem has been simply to determine who the "employer" is. A faculty member's employment contract is with the Board of Governors of his or her college; the Council of Regents is the bargaining agent and signs the collective agreement on behalf of management; the college administration administers the collective agreement and handles grievances; the Government, through the Ministry of Colleges and Universities, provides the staff for negotiations and is alleged by many to be calling the shots behind the scenes, especially on items having financial implications; and interposed among these agents are the Committee of Presidents and various other advisory committees drawn from college administration. Within and among these bodies there have been considerable differences of opinion as to the legitimacy of the union, whether to take an aggressive or conciliatory stance, and on goals and strategies with respect to major items in negotiation. Further, each of these agents has different access points for obtaining information on faculty and union attitudes and concerns, giving rise to different anticipations about the likely response of faculty to different management positions. Additionally, the day-to-day interactions between administration and faculty which do so much to colour the parties' perceptions and shape their demands occur in twenty-two diverse and dispersed colleges which vary widely with regard to the involvement and respect as professionals accorded faculty, management style, union militancy, and the quality of management-faculty relationships.

And yet, with all the potential for division that was inherent in the large, complex organizational structure, it appeared that there was a surprising degree of consensus in the system until the mid-Seventies, regarding the organizational goals of the CAATs and the means to achieve them. Union concerns tended to be concentrated upon the structure and process of bargaining - first, on the choice of bargaining agent, then on obtaining the right to strike - and on salaries. Few faculty challenged the vision of the system enunciated by the Government. Nor is there evidence that management felt faculty morale, commitment, or conflict to be one of the major issues in the CAATs.

\section{FROM 1977 TO THE PRESENT: LOW TRUST DYNAMICS AND THE BREAKDOWN OF THE SOCIAL CONSENSUS}

\section{Funding Cutbacks and the Breakdown of the Consensus}

The CAAT system was intended to consolidate nearly all publicly provided non-degree postsecondary and adult education and training in the Province, offer a quality alternative to university for all school leavers, address the needs of 
business and industry relative to the "technological revolution" and "knowledge explosion", and provide staff and facilities that would be on the cutting edge of technology, practice, and pedagogy. It was understood that this undertaking would be expensive, and the Government made a commitment to providing the required funds:

The proposed establishment of a network of colleges is an immense undertaking which will necessarily consume very large sums of money. [William Davis, Minister of Education, in his remarks to the inaugural meeting of the Council of Regents, 1966]

By the mid-Seventies, however, just as the largest cohorts of students were preparing to enter Ontario's colleges and universities, the Government claimed that there was a financial crisis and began to cut back on spending for postsecondary education. Whether these cutbacks were genuinely necessitated by fiscal conditions or reflected simply a change in the Government's spending priorities has yet to be established (see Skolnik and Rowen, 1984: 13-18, 124-133; Skolnik and Slaughter, 1987: 129-131), but the perception widely held among university and college faculty was that the latter was the case and that postsecondary education was bearing the brunt of an attack on the public sector that was driven by ideology not by revenue. And the cuts were substantial. Between 1978/79 and 1983/84, provincial operating grants per student in the CAATs declined in real dollars by one-third, while enrolment increased by fifty per cent (IARC: $32-33$ ). The Council of Ontario Universities and the Ontario Council on University Affairs estimated in 1983 that as a result of cutbacks, the university system was "underfunded" to the tune of 300 to 500 million dollars, or 20 to 35 per cent of total system revenue (Skolnik and Rowen, p. 138). While no agency produced analogous estimates for the CAATs, the funding recommendations in the IARC Report suggested an underfunding of 60 to 80 million dollars, or about 16 per cent of Government operating grants.'

The funding cutbacks contributed to a negative trust dynamic in several ways. First, the substantial reductions in funding were perceived by faculty as an indication that the Government was no longer as committed to its vision for the CAAT system as it once had been. Faculty in both the colleges and the universities took the cuts as a sign that the Government no longer valued so highly the work which they did, i.e. as a slap in the face. Further, faculty took as offensive, Government statements that the funding reductions would not impair quality, as they felt that there was a quite strong relationship between quality and real revenue per student. To faculty, those statements implied that the Government perceived there to be substantial fat, waste, or inefficiency in postsecondary education, a charge always certain to evoke anger from educators.

That this was indeed the Government's perception was suggested by the passion with which the Ministry and Council of Regents undertook to study the efficiency of the CAAT system (described in the IARC, pp. 73-74). Now those who manage educational systems must, of necessity, be concerned with efficiency, but they must balance this concern with at least equal attention to the quality of learning and other outcomes. Where this balance is lacking, teachers and students may rightly 
fear that their organizations are preoccupied with such things as numbers and money, to the debasement of intrinsically educational matters. This unfortunate state of affairs is exactly what the faculty perceived in the early 1980's, as the visible interest in efficiency was unmatched by any comparable studies of the quality of education in the CAATs - and, to boot, the discontinuance of external assessment of technology programs (IARC, p. 83).

As a result of the increased emphasis on efficiency, faculty picked up on the metaphors, first introduced by NDP members of the Legislature in the mid-Sixties, of the colleges as factories, and possibly 19th Century ones at that. This is a charge that has been made about various educational institutions from time to time, and has been developed analytically by Alexander Astin of the UCLA Institute for Higher Education Research. Astin distinguishes between the industrial production model and the humanistic model of postsecondary education institutions (1985: 14-17). In the industrial production model, the purpose of education is to maximize efficiency in the service of a jurisdiction's economic needs; in the latter it is to maximize the total human potential of students and staff.

These models imply quite different management styles. An institution which views itself as producing commodities for the market (i.e. skilled graduates for employers) will likely adopt a management style that is congruent with its production orientation, in Veblen's words, "principles and standards of organization, control, and achievement that have been accepted as an habitual matter of course in the conduct of business, will, by force of habit, in good part reassert themselves as indispensable and conclusive in the affairs of learning" (quoted in Astin, p. 15). In contrast, an organization which is committed to the total development of its students and staff is less likely to operate in a hierarchical mode and will not view students as raw material to be processed. It will be as concerned with organizational processes as with outcomes, appreciate the importance of developing its faculty, and heed Dennison and Gallagher's observation that "it would be an imprudent college that ignored the contributions that professional experts [the teachers] can make to college policy formulation, to priority setting, and to management and administration" (p. 207).

The CAAT model, as enunciated in the Basic Documents, has elements of both the industrial production and the humanistic models, and no doubt this ambiguity helped to produce the initial consensus. However, the ambiguity also created a situation wherein a slight shift in emphasis in either direction could cause some who were a party to that consensus to claim that the rules had been broken and that those who managed the system had broken with the faith. So long as there were abundant funds, there could be sufficient initiatives to placate both camps and the strains of pulling in two quite different directions could be tolerated. If the dominant management style was one of hierarchy and "collegiality when convenient but not necessarily collegiality", many faculty could nonetheless enjoy considerable autonomy through delegated roles in developing new programs, curricula, facilities, and sub-structures. When money became scarcer and efficiency a preoccupation, the fragile consensus upon which the CAATs began 
operations was in danger. Yet, notwithstanding the crucial role in this process of the breakdown of consensus that was played by money, it is important to note that the faculty revolt of the 1980's was not simply a revolt over funding; it was more a case that the financial stringency of the late Seventies and Eighties brought into greater visibility the inconsistencies in the CAAT value structure which earlier had been papered over by money.

Two other observations about the period of financial stringency are in order. First, though real operating funding per student declined substantially, capital funding was hit even harder. The horror stories of equipment shortage and obsolescence (except in some trendy programs) which are related in the IARC Report suggested that the element of the original vision which was for the CAATs to be on the cutting edge of technology was being compromised, and a very visible compromise it was. Second, there was a feeling among faculty that their time was being subjected to greater monitoring and control, and that written correspondence from management increasingly was replacing informal communication, in part no doubt a result of the increased size and complexity of the colleges. With a great enrolment expansion simultaneous with funding cutbacks in a labour intensive operation, faculty time had become the scarce factor, and management was under great pressure to use it most efficiently. An efficiency study done by the Ministry showed that of the 19.9 per cent reduction in operating cost per student between $1978 / 79$ and 1982/83, the vast bulk, 17.3 per cent, was from a reduction in unit teaching cost (Ontario, 1984). The major factors responsible for the reduction in teaching costs were increases in section size, reduction in the hours that students spent in class, and increases in contact hours for faculty. While the collective agreement provided for contact hours of faculty to vary at the discretion of management in relation to differences in class size, nature of subject matter, instructor's familiarity with the curriculum, and other factors, the IARC found that the vast majority of faculty were assigned nearly the maximum number of hours allowed for their category in the agreement. The Committee concluded that managing a CAAT was seen by many as consisting largely of devising ways of getting the maximum teaching hours, or student contact hours, out of faculty.

The combined effect of all the tendencies outlined in this section was to shatter the consensus that had existed earlier regarding the goals of the CAATs. But at the same time, the emphases on efficiency, the greater control of faculty time, and the increased formality in communication were all perceived by faculty as low trust initiatives. As Fox's trust model suggests, these low trust moves of management were met with counter moves in a low trust direction by faculty. Before considering the faculty reaction, it is necessary to examine the way in which the pluralistic nature of each constituency, management and faculty, was developing.

\section{Varieties of Management and Faculty Perspectives}

Earlier we commented upon the considerable fragmentation on what we may refer to collectively as the management side, which included the Government; the Minister of Colleges and Universities; the various sections of the Ministry, inclu- 
ding the Staff Relations Secretariat; the Council of Regents; the Committee of Presidents of the CAATs; and the administrators of each of the twenty-two colleges. Apart from the highest levels of this hierarchy, the differences of perspective and position were greater within the various sub-categories of management than between them. In general, three principal positions may be discerned.

First, there were those who enthusiastically supported the Government's strategy of edging the system toward a leaner, industrial production model preoccupied with efficiency. A trenchant example of this perspective is revealed in a letter which I received from a President shortly after the release of the IARC Report. Unlike some others who disputed the Report's claim that the colleges were being run along the lines of an industrial model, he acknowledged, at least "in a sense", the validity of that observation, but maintained that this was done "deliberately ... [in order] to achieve an atmosphere which combines facets of the world of business and industry in a teaching institution", i.e. the modelling of the hierarchical structure of industry was an intentional part of the learning environment. Another example was that of the administrators interviewed by the IARC who identified not as educators, but as taxpayers, arguing that the Province couldn't afford such an expensive college system.

Second were those, mostly from middle management, who voiced concern about the Government's running down of the colleges and viewing them as skills factories rather than educational institutions, and who tended to sympathize with faculty concerns. It was apparent in some of our college visits that these individuals had lost credibility with senior management, and though admired by faculty, did not enjoy much confidence from faculty as they were seen to be ineffective in pressing faculty concerns. Such persons appeared to have taken a stand on principle that proved costly to them both in terms of career prospects and influence within the college.

Between these two groups were those who quietly sympathized with faculty concerns, or were at least skeptical about Government policy, but who did little openly to challenge that policy or warn of its adverse effects on the colleges though some indicated that behind the scenes they lobbied for change. Recognizing the apparent futility of the efforts of the second group, the IARC empathized with the loyal dedication with which this group quietly tried to make the best of an increasingly bad situation. At the same time, we questioned the prudence of those in more senior positions who, while feeling that Government policy was having adverse effects, yet remained publicly silent about the matter. For one thing, their public silence contributed greatly to creating a rift at the college level between senior management and faculty; this was unlike the situation in the universities, where, even though the strident criticism of Government funding policy by senior institutional leaders was not successful in securing a change in funding policy, it did nevertheless help to maintain greater institutional cohesion than was the case for the colleges. Of perhaps even greater import was that as contrary information was increasingly filtered as it moved up through the bureaucracy, persons at the 
top were deprived of the data which might have caused them to alter their positions. Thus, without any direct contact with faculty, persons at the top of the system could confidently dismiss voiced faculty concerns as mischievous, irresponsible, and unfounded. Our interviews indicated also that those highest in the structure had little idea of the strength of faculty discontent. They did not expect that the refusal of the Council of Regents to entertain proposals for change in workload arrangements in 1984 would provoke a strike, whereas many persons at lower levels, with more contact with faculty, considered this a very likely possibility.

The differences of perspective among faculty were at least as great as those among management. I noted at least four principal perspectives among the many faculty and union leaders whom I interviewed. With the inevitable simplification which this sort of conceptual taxonomy involves, I offer the following categories:

\section{A. Unitary-Idealist}

This included persons with a strong professional identification who still maintained the unitary frame of reference which was characteristic of the early years of the colleges. They were uncomfortable with trade unionism and many viewed the colleges as a haven from the industrial strife of the business world. They remained proud of their association with the CAATs and felt that they could still fulfill at least some of the goals in the original vision even in reduced financial straits.

\section{B. Pluralist-Particularist}

This group is defined by its perception that there was a fundamental difference between their goals for the colleges and themselves and those of management, combined with a focus on local college matters of working conditions and/or the quality of education provided to their students. Many of this group had formerly identified with Perspective A, but had become burned out by adverse working conditions or cynical over what they perceived as the Government's betrayal of the original ideals upon which the system was established. In a more buoyant labour market, some of this group might have left the CAATs. While not ideologically committed to unionism, many could become enthusiastic union supporters if they saw the union as a useful tool in pursuing their ends. Others in this group were plain old-fashioned bread-and-butter unionists.

\section{Pluralist-Universalist}

This group brought universalist concerns about the social order to the college labour relations scene, viewing that arena as a battleground on which to wage a larger struggle against the Establishment which was then seen embodied in Ontario's Progressive Conservative Government. Their major concerns were not with changing the CAAT environment per se, but with the broad spillover and demonstration effects of reforms in the CAATs and with using the unionmanagement relationship in the CAATs as a springboard for launching more far 
reaching change. While initially a rather small component of faculty, this group grew as more CAAT faculty began to perceive that the funding cutbacks in the CAATs were part of a larger attack on the whole education system and public sector, and alliances were formed between the CAAT faculty and other public sector workers.

\section{Pluralist-Unionist}

This group consisted of hard-core and professional unionists whose chief concern was the advancement of the interests of OPSEU. Some saw the CAATs mainly as a vehicle to be used in the power struggle between OPSEU and the Progressive Conservative Government. In this connection it was pertinent that the CAAT academic unit was one of the only sizable groups in the Public Service that had the right to strike. Others possibly were interested mainly in their own advancement within the union hierarchy.

Although for expository convenience, I have associated these four perspectives with different groups, it is important to note that there were no readily identifiable blocs of faculty unequivocally identified with these different perspectives. Many faculty held more than one of these perspectives, and depending upon the circumstances could be motivated in a particular situation by one or another of these perspectives. The early 1980's was a period of flux in which the dominant perspective of faculty was subject to rapid and somewhat unpredictable change. I think that there was increasing momentum down the list of perspectives: the low trust dynamic initiated by management made the unitary-idealist perspective increasingly difficult to hold; the consciousness raising effects of interaction between CAAT faculty and their peers in other realms of the education system and public sector resulted in the particularism giving way to increased shades of universalism; and the increasing perception that only through the union could faculty hope to forestall their exploitation combined with a fear that the union itself was under attack by the Government led to greater identification with the union. The different perspectives could have been a source of fragmentation and dispersion of energy. That this was not the case was due to the genius or luck with which faculty opinion leaders seized upon the issue of workload and its mirror image, quality of education, as the rallying cry. I comment upon the significance of this issue in the next section, on faculty response.

\section{Faculty Response}

Before describing the content of the faculty response to the Government initiated moves which undermined the consensus upon which the CAATs were established, a methodological qualification is necessary. A strict application of Fox's trust dynamic model would involve tracing the myriad interactions of specific reciprocal statements and acts of the hundreds, perhaps thousands, of participants in the labour relations process in the CAAT system on an almost day to day basis. For example, a new interpretation of a specific collective agreement clause by one 
The Evolution of Relations Between Management and Faculty in

Dean in one college and the local response of faculty to that interpretation could be a significant "move and countermove" in the Fox model. To approach the analysis in such situational and chronological detail would be enormously complex and tedious and require voluminous narrative.

I have chosen instead to describe major general tendencies of each of the two aggregate parties (i.e. management and faculty) during major phases of the relationship. This heuristic simplification is useful in helping us to focus upon key tendencies, but it does oversimplify the complexity of the interactions. Specifically, it obscures the fact that some elements of what I have termed the faculty response may have occurred earlier than some elements of the initial management provocation, as the influence of faculty perspectives $C$ and $D$ would imply. Yet, on balance, I think that it is accurate to say that the galvanizing of sufficient faculty of perspective $B$, and the politicizing of sufficient numbers of those with perspective $\mathrm{A}$, to attain such a massive strike vote as was achieved in 1984 was largely a reaction to Government and management positions, not an autonomous happening - though faculty with persectives $\mathrm{C}$ and $\mathrm{D}$ were no doubt catalysts.

Faculty consciousness of and resistance to the directions toward which the Government began pushing the system in the mid-Seventies gained momentum slowly from the late-Seventies into the early-Eighties. This resistance began with increased insistence on formal rights under the collective agreement and increased numbers of grievances. The number of arbitration awards under Article 4, Instructional Assignments, increased from an average of about two a year in the late-Seventies to eight in 1982, eleven in 1983, and fifteen in 1984 (IARC, Appendix III). Collective bargaining became more confrontational. The IARC reported that "following the 1975/76 contract, negotiations have been protracted, frustrating experiences and have involved extensive third party assistance ... the parties' ability to use the negotiations process to establish collective agreements over the past ten years is not enviable" (p. 19). A fact finder's report in 1984 characterized the bargaining relationship as one of "conflict, intense competition, overt use of power, direct influence attempts, aggressive and antagonistic behaviour, a high level of distrust and denial of legitimacy" (quoted in IARC, p. 21). While the preceding quotation does not single out either party, comments from those present at the negotiating table suggest that the more intemperate remarks were more likely to emanate from the union side, not surprising given that the talks were making little headway on the major items in dispute and this was the side that was most frustrated with the status quo. In addition, CAAT faculty were increasingly participating in coalitions with others from the educational system and public sector in an effort to influence Government policy through political means.

Union strategy in bargaining increased concentration on workload, or instructional assignment, as it was somewhat euphemistically labelled in the collective agreement. Possibly this narrowing of focus was in part due to the Provincial Restraint Program which constrained salary bargaining, although the union also 
mounted an (unsuccessful) challenge of the Restraint Program. More importantly, workload was likely a far more significant issue to most faculty in the early-Eighties than salary. That is to say, given that workload for most CAAT faculty was significantly greater than was the norm for community colleges in North America, and CAAT faculty were probably the highest paid community college teachers on this continent, on the margin, most would probably have preferred a reduction of several hours of teaching to a few more percentage points of salary increase.

Workload was also inherently - both symbolically and tangibly - associated with the quality of education. Increased workload, in terms of increased student contact hours per teacher, had been the primary consequence of reduced funding, and the Government's alleged betrayal of the original vision of the colleges was seen to be intimately associated with money, workload, and making instructional assignments in a way that emphasized filling classrooms and timetables rather than the quality of education provided. The rhetoric with which union workload demands were clothed, in contrast, emphasized not the purely personal interests of teachers (except for equity), but that workload reduction was a necessary condition for improvement of the quality of education. The genius of the way in which the case for workload reform was presented was that it equated reduced workload with improved quality of education. Thus faculty of perspective B could agitate for workload reduction with no inhibitions about pursuing their own interests, and those of perspective A could identify with the rightness of the union position. This is not to say that there was anything untoward about linking workload with quality of education, for, by and large, the IARC concluded that there was at least a prima facie case that excessive workloads were impairing the quality of education (see pp. 85-86). However, developing this connection and presenting it effectively was a masterstroke of collective bargaining strategy - notwithstanding the initial management response to it.

\section{Management Response to the Workload Demand}

Management's response can be summarized rather succinctly: (a) there was no "general" workload problem in the system, though the possibility of isolated cases was conceded; (b) there was no evidence of a deterioration of the quality of education; (c) the union's proposed solution to the alleged workload problem, "the formula", was unwieldy, impossible to implement, and excessively costly, i.e. the cure was worse than the disease could possibly be imagined to be; and hence, (d) the proposed workload formula was not an appropriate subject for discussion in negotiations.

\section{The 1984 Strike and its Aftermath}

The next move by faculty was an overwhelming vote in favour of a strike. The strike occurred in November, 1984, and it was a jarring experience for most concerned, particularly as it was the first strike in the CAAT system (not counting 
the occasional and poorly supported one day walkouts over representation in the early years) and the first strike experience for most faculty and administrators. The colleges were concerned about permanent loss of students, seat purchases from the Federal Government, and credibility with industry, and the Minister was particularly concerned about the possible loss of the academic year for students. The faculty were legislated back to work, with all items outstanding - except the one that most felt had precipitated the strike - being referred to arbitration. Under Bill 130 (Ch. 43, S.O. 1984), the only issue that really mattered, workload, was referred to an ad hoc inquiry committee, the Instructional Assignment Review Committee.

The union reaction to the establishment of the IARC was indicative of how far the spiralling low trust dynamic had proceeded. I have every reason to believe that even as late as 1983, and possibly early in 1984, the union would have welcomed the establishment of a committee of neutrals that was charged with "conduct[ing] a comprehensive review of all aspects of instructional assignment in the colleges..." Yet, in April, 1985, when invited by the Committee to participate, the formal response of the provincial union was to boycott the proceedings and challenge the legitimacy and integrity of the process. The local response to the call for a boycott was uneven. Several local unions met with the Committee; a few sent personally abusive letters to the Committee, questioning our judgment or integrity in agreeing to serve; in a few colleges all randomly selected faculty declined to meet with us, but in all other colleges the vast majority of faculty who were invited to meet with us did so. A major concern expressed in almost every college was that we might be manipulated into concluding in favour of the Government position in the dispute, or that the Government would suppress or ignore our report if it did not support the Government position, i.e. that the process would not be fair. The union argued also that the establishment of the IARC was an inappropriate intrusion in the collective bargaining process. It maintained that in the first instance, the strike should have been allowed to run its course; and failing that, workload, like the other matters in dispute, should have been referred to arbitration. While I appreciate the principles that were invoked in these arguments, I believe, nevertheless, that the principal objection to the process was the concern that the union position would not be given fair treatment, a perception quintessentially associated with the low degree of trust which had come to characterize the relationship between the Government and the union ${ }^{2}$.

As the IARC Report has been widely disseminated, I will make only a few observations from it here, observations that are pertinent to the next stages in the development of faculty-management relations in the CAATs. First, we concluded that there were indeed "general" workload problems in the system and these likely did, or would shortly, compromise quality of education. Second, though tending to vindicate the union's analysis of the problem, we found serious weaknesses in the solution that the union proposed, a system-wide workload formula, and recommended an alternative approach which emphasized local negotiation of actual teaching and other contact hours for each program, subject, or discipline. 
The IARC Report was enthusiastically welcomed by the union and, apparently, the vast majority of faculty - though our strong recommendations for localization of bargaining were politely dismissed and I have yet to see a comment on our actual recommendations for dealing with workload. In their eyes, we were transformed overnight, as it were, from villains to heroes. Representative of this reaction, but with the singular literary flourish of Centennial College union newsletter, is the following passage:

What good will the Skolnik report produce? For many of us, its first benefit was an immediate and much-needed psychological boost. Before, during, and after last year's strike, when we protested the decline of quality education in our colleges, we sometimes felt like Columbus trying to convince a skeptical court that the world is round. "Give us a chance to prove it", we said. "Give us the ships and then see whether we sail off the earth". Queen Isabella ... didn't trust our words, despite our long experience in navigation, and instead referred our theory of the universe to the Spanish Inquisition (Skolnik's committee) for investigation. When Survival or Excellence? appeared, we were enormously pleased (and somewhat surprised) to see that the inquisitors had actually ruled in favour of the heretics for a change. [Unfettered, September, 1985: 7]

The reaction of management was more mixed and less public. I have not seen any published commentaries on the report from management representives. I have, of course, received numerous informal comments and heard, second-hand, of others. These have ranged from a few supportive comments, of a more temperate nature than the passage quoted above, to many which questioned the adequacy of the Committee's understanding of the purpose, role, and history of the CAATs. If the comments from the management side which I heard were at all representative of that side's reaction, the IARC report failed to convince management, by and large, of the seriousness of the workload problem - though the report may have garnered management support for the position it advanced on some of the other issues which it addressed, e.g. funding or professional development.

\section{The Government's Change of Heart on Workload}

If the IARC Report did not convince management of the seriousness of the workload problem, and certainly not of the desirability of a formula which the Committee recommended against, then the next step in the development of management-faculty relations was a most curious one indeed. That was management's rather sudden agreement, in Fall, 1985, to negotiate a workload formula of the type proposed by the union, and the same type which management had argued for over ten years would be extremely detrimental to the college system.

Several factors no doubt contributed to management's change of heart. One was the IARC Report, which even if unconvincing to management, created a public credibility gap for it. Another factor was the change in Government which had taken place in May, 1985. The new Liberal Government had, while in opposition, criticized the Progressive Conservative Government for its handling of the CAATs 
in general, and management-union relations in particular, and was anxious to establish more harmonious relations with the union. In addition, the Liberal Minority Government was dependent upon the support of the New Democratic Party, and the NDP had assured the union of its support in reaching "a fair settlement" of the workload issue. And yet, against these forces, the Committee of Presidents was still urging the management negotiating committee to avoid a major revision of the workload article (Amernic, 1988: 19-23).

Amernic, having interviewed many of those involved directly in the negotiations, reports that the management team felt that it had no choice but to agree to some type of formula and sell it as best it could to the Presidents. He suggests that the mangement team opted for a strategy of surprising the union with its own sudden proposal for a formula and an attempt to focus the negotiations on the cost implications of various numerical parameters of the formula, hoping in this way to limit the financial damage that would result from the formula. He suggests further that if the union were to refuse to consider costing information it would dissipate some of the goodwill that it then enjoyed at the Ministry, with the public, and with rank and file faculty who "were concerned about the survival of the CAAT system" (pp. 40-41). The image is of an aggressive management strategy, with the management team accepting that it was cornered and trying to gain whatever advantage that it could in the circumstances.

Amernic's case is argued persuasively and supported by quotations from bargaining team members. Still, I have problems with this interpretation of such a major reversal of policy. For one thing, the IARC offered management a viable alternative on a silver platter. As the union "kept trumpeting the IARC report" (p. 20), the management team could have solved whatever credibility problem it had by offering to accept the IARC recommendations on workload. This would have demonstrated a willingness to change the fabric of workload provisions significantly, and the union would have had a hard time discrediting the IARC recommendations. Further, once the initial element of surprise wore off, the management team would be right square where it had resisted being for at least ten years, in the middle of detailed discussions of the numerical parameters of the type of workload formula advocated by the union. Moreover, while cost was obviously a concern, management's principal objection to the formula had always been that it was unwieldy and would undermine the system's flexibility.

Thus, I am inclined to regard the statements of the management team about the cleverness of its blitzkrieg strategy as somewhat of a rationalization intended to elicit the confidence of the more hardnosed of the management cadre. Looking at these developments within Fox's model, I would offer a different explanation of management's change of heart. I think that the management team was tired of the strife and feared that continued confrontation would destroy the system. With a new Government in place that promised to revitalize the system, the time was ripe for management to try to reverse the spiralling low trust dynamic which could result only in disaster. Still feeling that the formula was a bad idea, but recognizing 
that the union could not give up its attachment to it, I see management's acceptance of the formula as a high trust initiative in which it attempted to change the dynamic of management-faculty relations in the CAATs.

Management's acceptance of the formula was accompanied by more than $\$ 60$ million being added to the system and several hundred new faculty appointments. Workload for most faculty was reduced, for some from 18-20 hours a week to as low as 14. In addition, the Government appointed a Special Adviser on Governance who, by and large, supported and further developed the IARC recommendations in this area. In January, 1987, the Minister announced the introduction of changes in governance, including the requirement of college councils and limited representation of faculty on Boards of Governors. None of these moves, and related ones in professional development, gave the faculty all that they wanted, but, given how frozen the system had been in these respects for over a decade, they might be regarded as not insignificant steps toward establishing a new era in management-faculty relations. At any rate, management felt that it had moved since Fall, 1984, and now it was up to the union and to faculty to respond.

\section{The New Era of Continuous Challenge}

If management expected that its concessions would earn it goodwill with the union and lead to some sort of mutual accommodation, its anticipation proved to be sorely incorrect. Even though it involved significant workload reductions for the majority of faculty, the early experience with the workload formula which was implemented in 1986 has been characterized by a plethora of faculty complaints over the interpretation and application of the formula. My interviews with administrators in several colleges, including management members of the joint union-management workload monitoring committees, indicates a perception among management that many of these complaints are mere attempts to manipulate the formula to the advantage of the faculty member rather than to redress demonstrably inequitable or excessive workloads. I hasten to add that these are management perceptions which I am reporting here, not the conclusions of impartial studies, for which the necessary data would be impossible to obtain. Examples which managers have given me of complaints which they view as bordering on petty include the following: attempts by faculty to get the essay evaluation factor, which is the highest evaluation factor in formula, for short answer quizes, of even just a few words; requests for special workload credit for activities which might be considered normal responsibilities of teachers, e.g. consulting with a substitute teacher about a class held while a faculty member was away sick, or for time spent photocopying assignment instructions (which one might think would be covered by the preparation allowance in the formula); and seeking credit for a larger course enrolment than one has because other teachers have a larger course enrolment for which they get credit in the formula. It may well be that there is more in these complaints than meets the eye, or that they have been provoked by management attempts to manipulate the formula in other respects, 
as I have seen claimed in some local union newsletters. Nevertheless, the existence of such complaints suggests the opposite of the type of give-and-take atmosphere which characterizes a high trust relationship; that the acceptance by management of the formula has not resulted in a weakening of the low trust dynamic under which the colleges have suffered for many years.

Another perception about the workload determination process which has been related to me by numerous managers pertains to the College Workload Monitoring Committees which attempt to resolve workload complaints. The perception is that the union representatives typically vote as a bloc, indiscriminately in favour of the faculty side in a dispute. Deadlocks are resolved only when one or more members of the management side decide in favour of the complainant in order to avoid conflict or to be seen making a conciliatory gesture to the union. Management thus perceives that its hope for a new era of joint problem solving has not been realized, and that the concessions which it made in the workload determination process have been abused.

The aggressiveness with which the union has challenged management interpretation and application of the new workload article has been matched by equally aggressive attempts to make further gains in this area in the next round of bargaining. The principal focus of union demands in the bargaining which commenced in 1987 was workload. This has been demoralizing to a management which felt that it had made unprecedented concessions in that area in 1986 and that it would be prudent to have at least a few years' experience with the new workload system, and time to analyze that experience, before making significant changes to it. As well, having just gotten an additional $\$ 60$ million put into the colleges' base operating budgets, management sees little likelihood of obtaining additional funds to reduce workload further. To management, the negotiation of the workload article is the most time-demanding, tedious, and draining area, and it dreads the prospect of having to become mired year after year in such negotiations. ${ }^{3}$

A third area of union militancy is that of faculty participation. The colleges began in 1987 to establish academic councils of the types recommended by both the IARC and the Pitman Reports. In most colleges, however, the establishment of councils has been marked by disputes about its composition, constitution, or scope of authority. In some cases, the major issue has been whether the teachers who sit on the council would be representatives of the union or of faculty. Management has maintained that it is the professional role and expertise of faculty, not their union affiliation, which warrants them participation on academic councils though why this did not warrant such participation prior to the Minister's edict in January, 1987 is not clear. Management acknowledges that faculty have legitimate employment interests, but argues that the collective bargaining process provides an adequate vehicle for the representation of those interests.

Those who favour the union representation model argue, on the other hand, that the legitimate concerns of the union go beyond bread and butter issues, one of the most vital of other concerns being quality of education. Taking a pluralistic view, they tend to see management as just another interest group with no more stake in, 
or claim to speak for, quality of education than the union. As some feel that management has allowed the quality of education to deteriorate, they would see union involvement in quality of education issues as a healthy thing. Needless to say, statements like the previous one are tantamount to waving a red flag in front of many managers. Nor are faculty themselves united on this issue. A local union newsletter in one college noted that in a meeting with Mr. Pitman, some faculty maintained that the only valid representation must come from the union, while "others insisted that the union had an agenda of its own, and did not necessarily always represent the best interests of the majority of the faculty" (Humber Faculty Newsletter, April 1986: 2). Yet another contentious issue with respect to the councils has been that of workload credit for participation, with one side maintaining that professionals should not ask for time off for such purposes, the other arguing that to expect faculty to take on this role without extra credit borders on exploitation or implies a wish to undermine faculty participation.

The responses of the union, and many faculty, to management initiatives with respect to faculty participation imply that the respondents view the form of these initiatives as indicating low trust. Whether this is the case is often difficult to judge. One management initiative, however, which seems very clearly to convey a low trust message to faculty is the recent announcement that the membership of Boards of Governors will be "opened up and strengthened" to include one faculty member (and one student, one administrative staff member, and support staff member), but that the faculty member (and other internal members) will not have voting rights pending a review of potential conflict of interest questions over the next two years (Ontario, 1987). As college faculty are represented, with voting rights, in nearly all other provinces which have independent governing boards, it is difficult to see the rationale for such caution in Ontario, except out of fear that faculty will abuse this privilege - a quintessentially low trust view.

Taken together, the various actions and statements of the union since 1984 would seem to suggest that the relationship has now entered the phase which Fox describes as the Continuous Challenge Pattern:

Here we find the workgroup refusing to legitimize management's claim to assert and pursue objectives which are seen as overriding certain interests, practices, or values of the group. The group may, of course, be forced to submit but it continues to withhold legitimacy; fighting guerilla skirmishes wherever possible, seeking always to undermine management's position and aspiring to mobilize enough power for an effective challenge... A management working to the doctrine of mutual accommodation will expect that an concessions it offers to be met halfway, but instead it finds that concessions merely prompt the group to raise the stakes of the contest by enlarging its claims. (pp. 310-312).

\section{Conclusions and Prognoses}

This essay began by suggesting that the suspicion and distrust which characterize the relationship between faculty and management in the CAATs constitute the most serious barrier to academic development and excellence in the colleges. We 
The Evolution of Relations Between Management and Faculty in 109 Ontario Colleges of Applied Arts and Technology

then traced the development of management-faculty relations from the early years of inspired social consensus, through the period in which the Government appeared to have provoked the dissolution of that consensus, to the present state of continuous challenge.

Fox observes that the repudiation of the legitimacy of management which defines the continuous challenge model can stem from either of two sharply contrasting orientations, universalist or particularist. Under the former, the challenge to management is part of a social philosophy which rejects the existing economic and social order and "inspires action on behalf of all employees as victims of oppressive hierarchical power". Under the latter, the challenge to management derives from the specific workplace concerns of the group in question and its doubt that management, at its most fundamental level, is committed to the best interests of the group. He notes further that these two orientations are most difficult to distinguish in practice. Particularist ends are often pursued under the rhetorical cloak of "universalist appeals for justice and equality"; universalist ends may be legitimized and sold to rank and file through seizing upon particularist grievances. In CAAT labour relations, there are indications of both particularist and universalist sentiments and strategies, and it is difficult to determine which is dominant.

Insofar as the continuous challenge pattern in the CAATs reflects an increasingly universalist orientation on the part of faculty, and acceptance of the inevitability of irreconcilable class war, there would seem to be little hope for a sustained improvement in this relationship, only temporary "periods of armed truce as each side licks its wounds and watches the enemy for signs of a weak spot in its defences" (Fox, p. 311). Improvements in those colleges where the universalist orientation of faculty is weak would be possible were the present provincial bargaining structure to be replaced with local bargaining, as recommended by both the IARC and Pitman - but given the power and preferences of the central bargaining agents, this reform seems unlikely.

Following Fox, I submit that the validity of the universalist characterization of management-faculty relations, with its stirring class war rhetoric, is not a matter of objective fact, but a function of perception, specifically whether it describes the dominant perception on either side of the relationship. If alternatively, the dominant perceptions are those of a particularist orientation, then some type of pragmatic compromises which could reverse the present low trust dynamic, and ultimately lead to a win-win option, are possible, at least in principle. However, given the acrimonious history of this relationship, the diversity and fragmentation of points of contact, and the paucity of human relations training on both sides, the search for compromise will be difficult and risky.

Given its greater control over the agenda, the primary initiatives for change must come from management; and if the quality of the relationship is to change, these initiatives must be of a high trust nature, i.e. making itself vulnerable in ways where the potential for harm if the trust is abused exceed the gains that will result if the trust is not abused, such as giving faculty a vote on governing boards, or 
meaningful say in academic decisions. Management may feel that the risks involved in such actions are too great, especially if its diagnosis of the relationship leads it to perceive that the universalist orientation is dominant among faculty. If so, that will be the end of the search for a higher trust alternative to continuous challenge.

Should management decide to take the risk - and not just pretend to do so, which would make the present bad situation even worse - the onus will be on faculty to decide how they wish to respond. Should they wish to cling to a universalist orientation, feeling that any accommodation would betray their ideology, they no doubt will reject management overtures, alleging them to be insincere. If, on the other hand, faculty should choose to seek pragmatic resolution of their particularist grievances, they will have to be willing to make some high trust responses, i.e. make themselves vulnerable also, to do so. Ultimately, in spite of, or more likely because of, its sheer simplicity, Fox's concept of trust would seem to offer a most insightful perspective on management-faculty relations in the CAATs. It is a concept, the pursuit of which is laden with risk, but also with potential for great benefit for all who have a stake in the Colleges of Applied Arts and Technology.

\section{NOTES}

1 While this estimate was dismissed by the Minister of Colleges and Universities in August, 1985 as "a little bit facile", in May 1986, he announced that the Government was injecting an additional $\$ 60$ million into the CAATs "to improve the quality of education" (The Globe and Mail, August 3, 1985: 15; Ontario Hansard, May 29, 1986: 1006).

2 When asked to rule on the workload issue, the arbitrator held that he had no jurisdiction over it, unlike the other outstanding items in dispute, and that there was nothing unlawful about this restriction of his jurisdiction. As for my own involvement in the process, when I first accepted the Chairmanship of the IARC, in January, 1985, I was not aware of any questions about its legitimacy. By the time that I developed an appreciation of the union's concerns about its legitimacy, as these were pointed out to me in May, I was well into the study, and felt that a resignation would have contributed more to perpetuating the problem than to its solution. As I considered myself to be as impartial and competent for this task as anyone who might replace me, and that the Committee had been duly established by the Legislative Assembly of Ontario and would go ahead in any event, I felt responsible to complete the job that I had started whatever reservations I developed along the way.

${ }^{3}$ The most contentious issue in the 1987-88 negotiations, which were completed subsequent to the preparation of this manuscript, was the union's demand to equalize maximum teaching hours for all teachers. Management regarded this as an irksome and costly demand unrelated to any real problem of equity or quality. In view of the substantial variation in teaching situations, Gandz termed this demand, 'untenable'. The IARC also had concluded that substantial variation in maximum teaching hours was warranted. Apparently faculty were divided, as the negotiating team's call for a strike mandate was voted down by a small majority. Faculty with whom I spoke suggested that in concrete (particularist) terms, the issue was not of sufficient magnitude to warrant a strike; but that a vote in favour of strike could have been a way of voicing lack of confidence and trust in management (i.e. universalist concerns). The stalemate in negotiations was broken when the issue was referred to a joint study committee with recourse to arbitration. 
The Evolution of Relations Between Management and Faculty in

111 Ontario Colleges of Applied Arts and Technology

\section{REFERENCES}

Amernic, J.H. (1988, forthcoming). Accounting and Collective Bargaining in the Not for Profit Sector. Hamilton, Ontario: Society for Management Accounting.

Astin, A. (1985). Achieving Educational Excellence. San Francisco: Jossey-Bass publishers.

Davis; W.G. (1966, January 18). Address to Inaugural Meeting of Council of Regents of Ontario Colleges of Applied Arts and Technology. Toronto.

Davis, W.G. (1970, February 16). Memorandum to the Faculty Members of Colleges of Applied Arts and Technology. Toronto.

Dennison, J.D., and Gallagher, P. (1986). Canada's Community Colleges. Vancouver: University of British Columbia Press.

Deutsch, M. (1962). "Cooperation and Trust: Some Theoretical Notes." in Marshall R. Jones (ed.), Nebraska Symposium on Motivation. Lincoln: University of Nebraska Press, pp. 275-319.

Fleming, W.G. (1971). Ontario's Educative Society, Vol. 4, Postsecondary and Adult Education. Toronto: University of Toronto Press.

Fox, A. (1974). Beyond Contract, Work, Power, and Trust Relations. London: Faber and Faber.

Gandz, J. (1988). The Report of the Colleges Collective Bargaining Commission. Toronto: Ontario Ministryof Colleges and Universities.

Hamblin, F. (1984). "An Analysis of the Policy Formation Process Leading to the Establishment of The Colleges of Applied Arts and Technology of Ontario." Ed. D. Thesis, University of Toronto.

Humber Faculty Newsletter. (1986, April). Report on Governance, by Laurie Turner. OPSEU Local 562, Vol. 1, No. 4, p. 2.

Instructional Assignment Review Committee, M.L. Skolnik, Chairman. (1985). Survival or Excellence? Toronto: Ontario Ministry of Colleges and Universities.

Little, His Honour Judge W. (1969, May). Collective Bargaining in the Ontario Government Service. A Report Submitted to the Lieutenant Governor of Ontario.

Ontario. Department of Education. (1966, June). Colleges of Applied Arts and Technology: Basic Documents. Toronto.

Ontario. Hansard, Legislative Assembly of Ontario. (1986, May 29). Statement by the Hon. Gregory Sorbara, Minister of Colleges and Universities. p. 1006.

Ontario. Ministry of Colleges and Universities. (1984, June). An Analysis of Unit Operating Costs in the Colleges of Applied Arts and Technology, 1978-79 to 1982-83.

Ontario. Ministry of Colleges and Universities. (1987, January 14). Release of Statement by the Hon. Gregory Sorbara, Minister of Colleges and Universities.

Skolnik, M.L. (1987). "Role Conflicts of a Professor of Higher Education: An Autobiographical Case Study." In W. Shere and R. Duhamel (eds.), Academic Futures: Prospects for Postsecondary Education. Toronto: OISE Press, pp. 108-127.

Skolnik, M.L., and Rowen, N.S. (1984). "Please, Sir, I Want Some More' : Canadian Universities and Financial Restraint. Toronto: OISE Press.

Skolnik, M.L., and Slaughter, S. (1987). "Continued Efforts to Cope with Declining Resources: Selected Postsecondary Systems in Canada and the United States." Higher Education, Vol. 16, No. 2, pp. 125-134.

Smyth, D.M. (1970). "Some Aspects of the Development of Ontario Colleges of Applied Arts and Technology." University of Toronto, M. Phil. Thesis.

The Citizen, Ottawa. (1977, April 18). "Community College Teachers Change Union", p. 15.

The London Free Press. (1977, April 18). "Fanshawe Teacher Heads Union Split on Faculty Concern", by Joanne Ramondt, p. 20.

The Globe and Mail. (1970, February 2). "Community Colleges Face One-Day Teachers' Strike", p. 1. 
The Globe and Mail. (1985, August 3). "Morale is 'Alarmingly Low' at Community Colleges: Report" by Lorne Slotnick, p. 4.

The Toronto Star. (1974, September 16). "5,500 Teachers in 22 Colleges Plan Walkout", by Elaine Carey, p. 4

Unfettered (1985, September). News and Views from OPSEU Local 558, Centennial College,Vol. 2 ; No. 1, p. 7 .

Watson, C. (1971). Innovation in Higher Education, Canadian Case Study: New College Systems in Canada. Toronto: Ontario Institute for Studies in Education.

Zand, D.E. (1972). "Trust and Managerial Problem Solving." Administrative Science Quarterly, Vol. 17, No. 2, pp. 229-239.

Zwelling, M. (1971, March 23). "Community College Teachers to Vote on Union". The Toronto Telegram. Clipping in archives, Centre for Industrial Relations, University of Toronto, page number not available. 